\title{
Iron Enrichment In Laterites Soils From Selected Regions In Kenya Using Magnetic Separation
}

\author{
Mutembei, P. Kugeria, Naftali. T. Muriithi, Jackson, W. Muthengia \\ ${ }^{I}$ Chemistry Department, Kenyatta University, P.O. Box 43844-00100 NAIROBI, KENYA. \\ ${ }^{2}$ School of Pure and Applied Sciences, Embu University College, P. O. Box 6-60100, EMBU KENYA \\ Author to whom all enquiries should be addressed. Tel., 254721450047. E-mail address
}

\begin{abstract}
Laterites also known as murrams from selected sites in the Republic of Kenya were analyzed for chemical and mineral content with particular interest in iron. In Kenya, laterites are only used mainly for surfacing roads. This study set out to show that laterites can be converted to high-quality iron ore which should make any country self-reliant in as far as supply of metallic iron is concerned. The samples of the study were obtained from Tunyai Division, in Tharaka Nithi County, in the Republic of Kenya. The samples were concentrated by heating charcoal/laterite mixtures in the ratios of 1:10 by mass in a slow current of air and in the temperature range of $500-700^{\circ} \mathrm{C}$. Elemental analysis was carried out on both the raw laterites and the heat treated samples using Atomic Absorption Spectroscopy and EDTA Titrations. The minerals present were determined using a Bruker D8 Advance Diffractometer. The results of elemental analysis showed that, raw laterites contain 28-31 percent by mass iron. After the heat treatment, the level of iron, in the heat-treated sample had increased to 55-64 percent by mass. Iron ore with this level of concentration is usually what is put in a blast furnace during extraction of iron from iron ores. The X-ray diffraction data confirmed that, iron in the raw laterites was present predominantly as the minerals goethite and hematite. Heat treated laterite was found to have magnetite, formed from the goethite and hematite. The iron present in laterites was, therefore, concentrated using magnetic separation.
\end{abstract}

Key Words: - Beneficiation, iron, laterites, Goethite, Magnetite, Hematite.

\section{INTRODUCTION}

Iron is the fourth most abundant element in the earth's crust after oxygen (45.5 percent, silicon 27.2 percent, and aluminum, 8.3 percent) with a relative abundance of 6.3 percent $^{1}$. Iron-made products, for example, are produced in larger tonnage than that of all the other chemical elements combined. Most iron ores mined today contain the minerals hematite $\mathrm{Fe}_{2} \mathrm{O}_{3}(70$ percent $\mathrm{Fe}$ ), goethite $\mathrm{FeO} . \mathrm{OH}$ (63 percent $\mathrm{Fe}$ ), limonite $\mathrm{FeO}(\mathrm{OH}) \cdot \mathrm{nH}_{2} \mathrm{O}$ ) (up to 60 percent $\mathrm{Fe}$ ), and magnetite, $\mathrm{Fe}_{3} \mathrm{O}_{4}(72.4 \text { percent } \mathrm{Fe})^{1}$. Most of the world's important iron ore sources occur in iron-rich sedimentary rocks known as Banded Iron Formations (BIF). These BIF are almost exclusively of pre-Cambrian age (greater than 600 million years old) and occur in all continents. In many instances, they are mined as iron ores, but most importantly they are the source rocks for most of the large high-grade concentrations of iron ore currently mined throughout the world. ${ }^{2}$ The BIF enrichment deposits comprising of hematite and goethite are the most important in regard to resources and production. The iron content of these ores varies widely between 18 and 60 percent. In any case, with the exception of very few ores such as that from Kiruna Mine in Sweden, ${ }^{3}$ most ores mined are unsuitable for feeding into a blast furnace and some ore beneficiation must be carried out.

Reports from Geological Surveys have shown that Kenya has large economically viable iron deposits. Preliminary exploration by the Department of Geology and Mines has established that the country has sufficient quantities of iron ore and limestone to sustain the development of steel manufacturing plants. Deposits such as one in Ikutha in Kitui District has 68 percent Fe, Marimante in Meru has 46 percent Fe while Macalder has 45.25 percent $^{4}$. The ore in Kitui has iron concentration which is as high as the best iron ore in the world found at Kiruna mine in Sweden, with 68 percent iron $^{3}$. China Mining Association (2011), reports that intensive prospecting over the past few years has yielded promising data on availability of iron ore in the country. Currently, a privately owned Kenyan Mining Company is mining iron ore at Kishushe Location in Taita Taveta County. The company is targeting 30,000 tonnes of iron ore from the Kishushe site. The report from the China Mining Association (2011) adds that another Chinese based company was also planning to collaborate with the Kenyan Company in setting up of a local steel manufacturing plant ${ }^{5}$.

Laterites are soil types which are rich in iron and formed in hot and wet tropical areas. Nearly all laterites are rusty-red because of iron (III) oxides ${ }^{6}$. Lateritic materials, also known as Murrams consist of 15 to 40 percent iron and their main application is roads surfacing in Kenya ${ }^{7}$. Iron ore deposits with this level of iron are currently being used in other countries as a source of iron after ore concentration. ${ }^{8,9}$ Iron from these soils 
can be concentrated using methods such as jigging, magnetic separation and froth flotation. Different techniques used depend on the minerals being concentrated. Magnetite for instance, is concentrated using magnetic separation, while hematite is concentrated using froth flotation ${ }^{10,11}$. Recently, Purwanto and co-workers (2003) have concentrated iron in sand beaches using $\mathrm{CO} / \mathrm{CO}_{2}$ at temperatures of about $673 \mathrm{~K}$. The chemical equation involved in the process is given in equations 1 and $2 .{ }^{12}$

$$
\begin{aligned}
& \mathrm{Fe}_{2} \mathrm{O}_{3} \cdot \mathrm{H}_{2} \mathrm{O}(\mathrm{s}) \stackrel{400-500^{\circ} \mathrm{C}}{\longrightarrow} \mathrm{Fe}_{2} \mathrm{O}_{3}(\mathrm{~s})+\mathrm{H}_{2} \mathrm{O}(\mathrm{g}) \ldots \ldots . . \\
& 3 \mathrm{Fe}_{2} \mathrm{O}_{3}(\mathrm{~s})+\mathrm{CO}(\mathrm{g}) \stackrel{600-700^{\circ} \mathrm{C}}{\longrightarrow} 2 \mathrm{Fe}_{3} \mathrm{O}_{4}(\mathrm{~s})+\mathrm{CO}_{2}(\mathrm{~g}) .
\end{aligned}
$$

At temperature of $400-500^{\circ} \mathrm{C}$, goethite was converted to hematite. At temperatures of $600-700{ }^{\circ} \mathrm{C}$, hematite was converted to magnetite ${ }^{12}$. Magnetite could therefore be separated from the heat treated sample by use of a strong magnet. The $\mathrm{CO} / \mathrm{CO}_{2}$ gas was first generated from elsewhere which was later used to reduce goethite to magnetite. In the current study, Purwanto and co-workers' (2003) technique of preparing $\mathrm{CO} / \mathrm{CO}_{2}$ gas and reduction of beach sand has been modified. In the study, laterite-charcoal mixture in the ratio of 10:1 by mass was heated in the temperature range of $500-700^{\circ} \mathrm{C}$ in a current of air and the concentration of the iron was raised from about 30 percent to 64 percent. Carbon (II) oxide (a reducing agent) was produced in situ which thereafter reduced iron oxides in laterites to magnetite.

\section{Sampling}

\section{METHODS}

Sampling was done randomly from ten localities of Tunyai Division in Tharaka Nithi County. The ten localities were Gitong'o, Gitara Kianderi, Kibuuka, Kithino, Kianamuthi, Kamujwa, Kinyuru, Mithigini, Ntendera and Tubui regions, located at latitudes $0^{\circ} 10^{\prime} 26^{\prime \prime} \mathrm{S}$ to $0^{\circ} 12^{\prime} 52^{\prime \prime} \mathrm{S}$ and longitudes $37^{\circ} 48^{\prime} 40^{\prime \prime} \mathrm{E}$ to $37^{\circ} 49^{\prime} 12^{\prime \prime}$ E. Three sampling sites were selected within a distance of about a $\mathrm{km}$ in a given region. Within a given sampling site, the surface materials of up to $30 \mathrm{~cm}$ deep were removed because it contained a lot of organic matter. About one $\mathrm{kg}$ of sample was obtained from this depth and packed in plastic bags then labeled 'level A'. In the same hole a further one meter depth and $30 \mathrm{~cm}$ wide was dug and samples collected and packed then labeled 'level B' ready for analysis.

\section{Sample treatment and analytical procedures}

About a kilogram of each laterite sample was weighed and put into a paper bag and transferred into the oven for drying at $105^{\circ} \mathrm{C}$ for 9 hours. Samples were removed from the oven and cooled, then pulverized to 300 microns (150 meshes) using a pulverizer. Minerals present were determined using Bruker D8 Advance Diffractometer. Chemical analysis was carried out using AAS. Other pulverized laterite samples were reduced using charcoal and concentrated using magnetic separation.

\section{Chemical analysis using AAS}

About $0.100 \mathrm{~g}$ of the pulverized sample was weighed and put into a labeled 125-ml plastic bottle. About $1 \mathrm{ml}$ of concentrated aqua-regia (mixture of concentrated $\mathrm{HCl}$ and $\mathrm{HNO}_{3}$ in the ratio 3:1) was added followed by $3.0 \mathrm{ml}$ of hydrofluoric acid. The samples were left to digest for 8 hours. $50.0 \mathrm{ml}$ of concentrated boric acid was added in each container and left to digest for one hour. Distilled water was added to make the total volume of $100.0 \mathrm{ml}$. Syenite (SY-3) and Mount Royal Gabbro (MRG) rock standards were also digested following the same procedure used to digest the samples. Dilutions of the sample solutions were made by putting $5.0 \mathrm{ml}$ in 100-ml labeled volumetric flask and made up to the mark using distilled water. The elemental analysis was done on samples using AAS instrument (Spectr AA.10 model from SEANAC Company).

\section{X-ray Diffraction (XRD) Analysis}

About $30 \mathrm{~g}$ of pulverized laterite samples was put in sample holders. They were loaded for analysis of minerals using data collector software. Results of analysis of minerals present in each sample were given using Bruker D8 Advance Diffractometer.

\section{Concentration of iron in laterites}

$30.0 \mathrm{~g}$ of laterite sample and $3.0 \mathrm{~g}$ of charcoal powder was mixed and transferred into fire clay crucibles. The mixture was heated at temperature range of $500-700{ }^{\circ} \mathrm{C}$ in controlled current of air for 2 hours using a charcoal burner shown in plates 1 and 2 . 


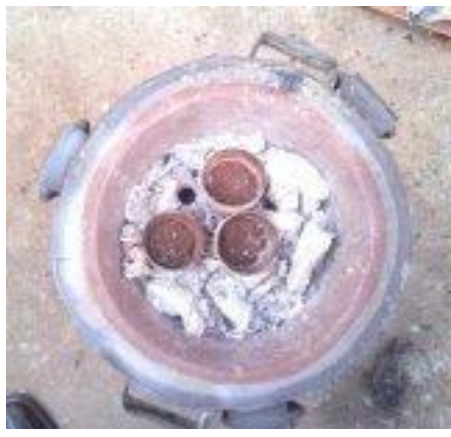

Plate 1. Charcoal Burner with fire clay crucibles containing laterite-charcoal mixture.

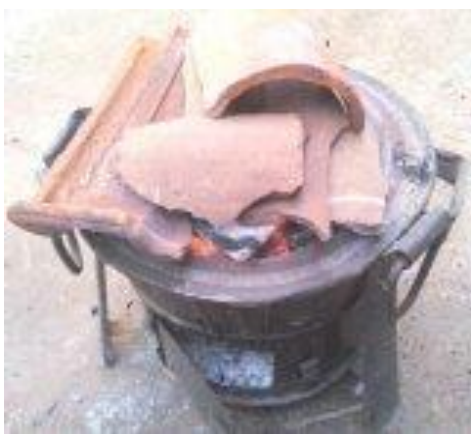

Plate 2. Charcoal Burner with laterite-charcoal mixture heated in a controlled air current.

After 2 hours, the roasted samples were allowed to cool to room temperature, and then transferred into a rotating magnetic separator. Serial separation was done on the samples by returning the concentrate three times into the rotating magnetic separator. The mineralogical and elemental compositions for the concentrate were determined using XRD and AAS as described previously.

\section{RESULTS AND DISCUSSION}

Mineralogical composition of the raw and beneficiated laterite samples using magnetic separation method

The figure 1 and 2 shows XRD spectra for both raw and beneficiated laterite samples from two of the selected sites.

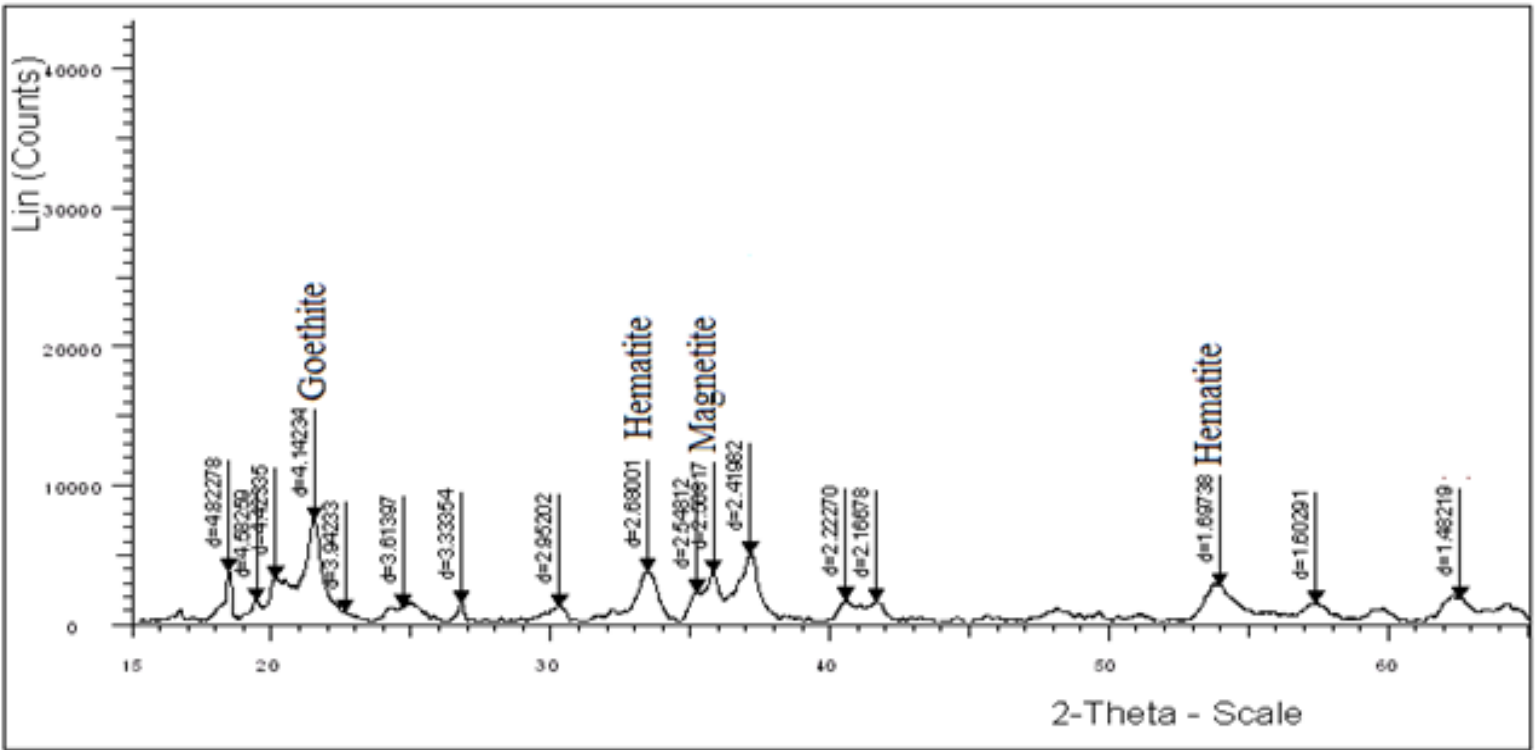

Figure 1(a) - XRD Spectrum for raw laterites from Kibuuka region at level a with $26.46 \%$ iron 


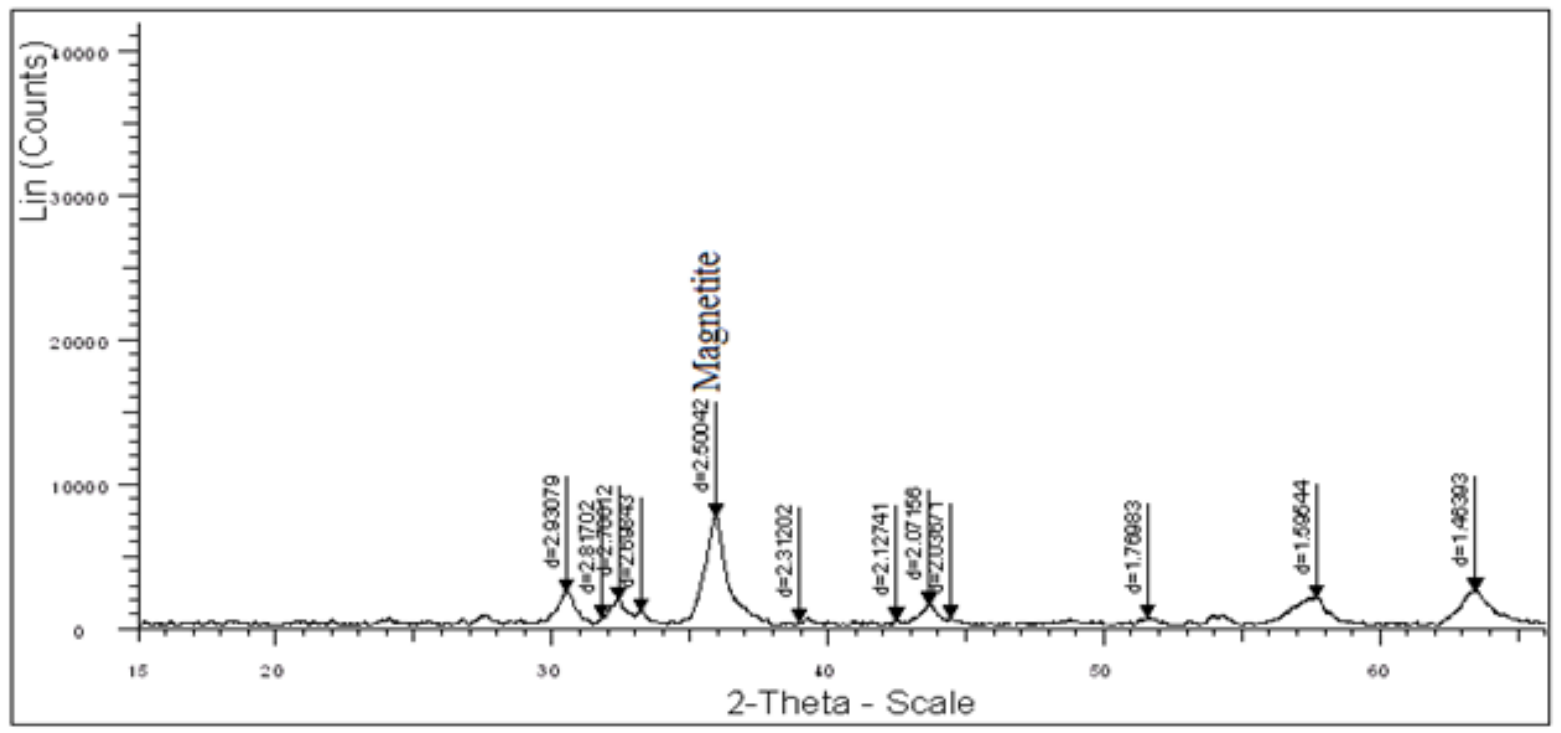

Figure 1(b)- XRD Spectrum for beneficiated laterites from Kibuuka region at level a with $62.59 \%$ iron

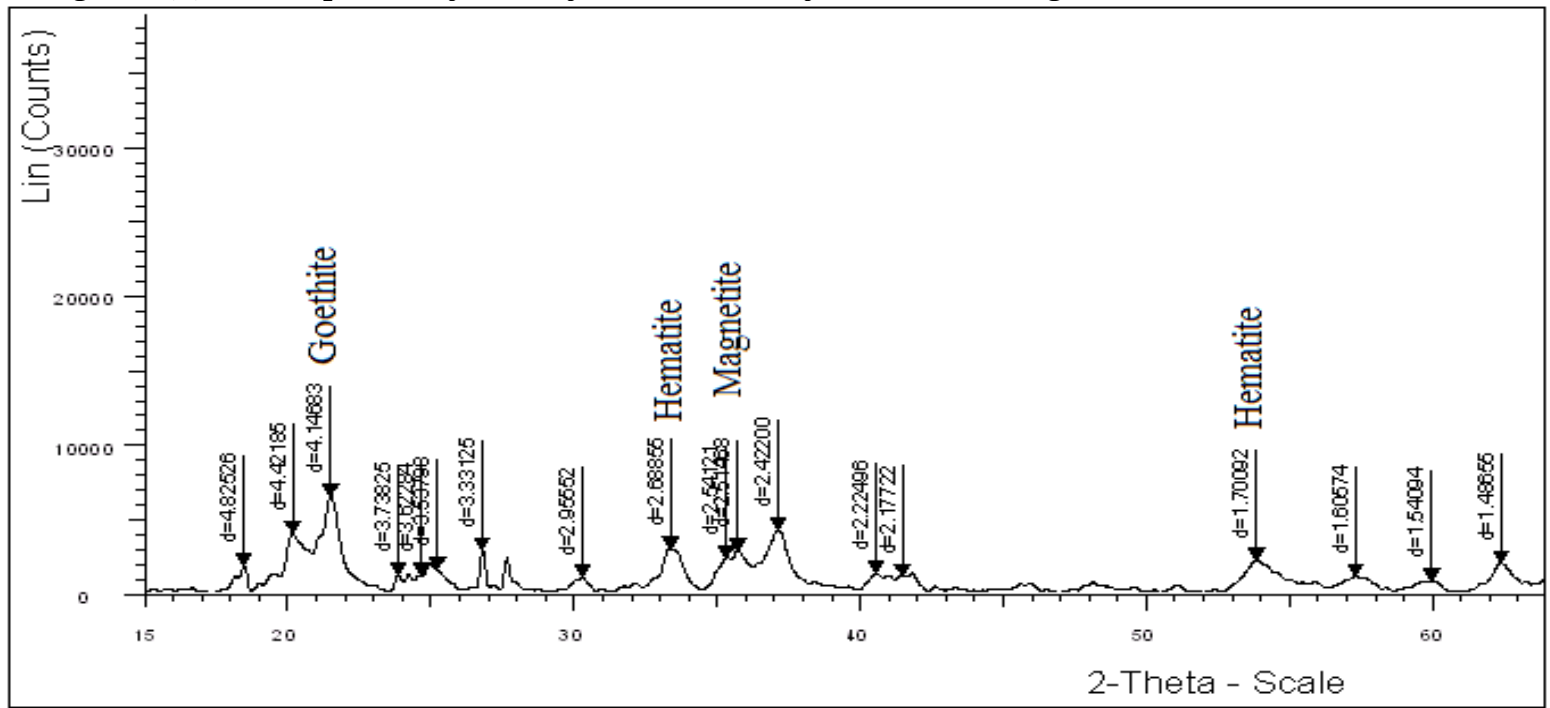

Figure 2(a) - XRD Spectra for raw laterites from Ntendera region at level a with $32.12 \%$ iron

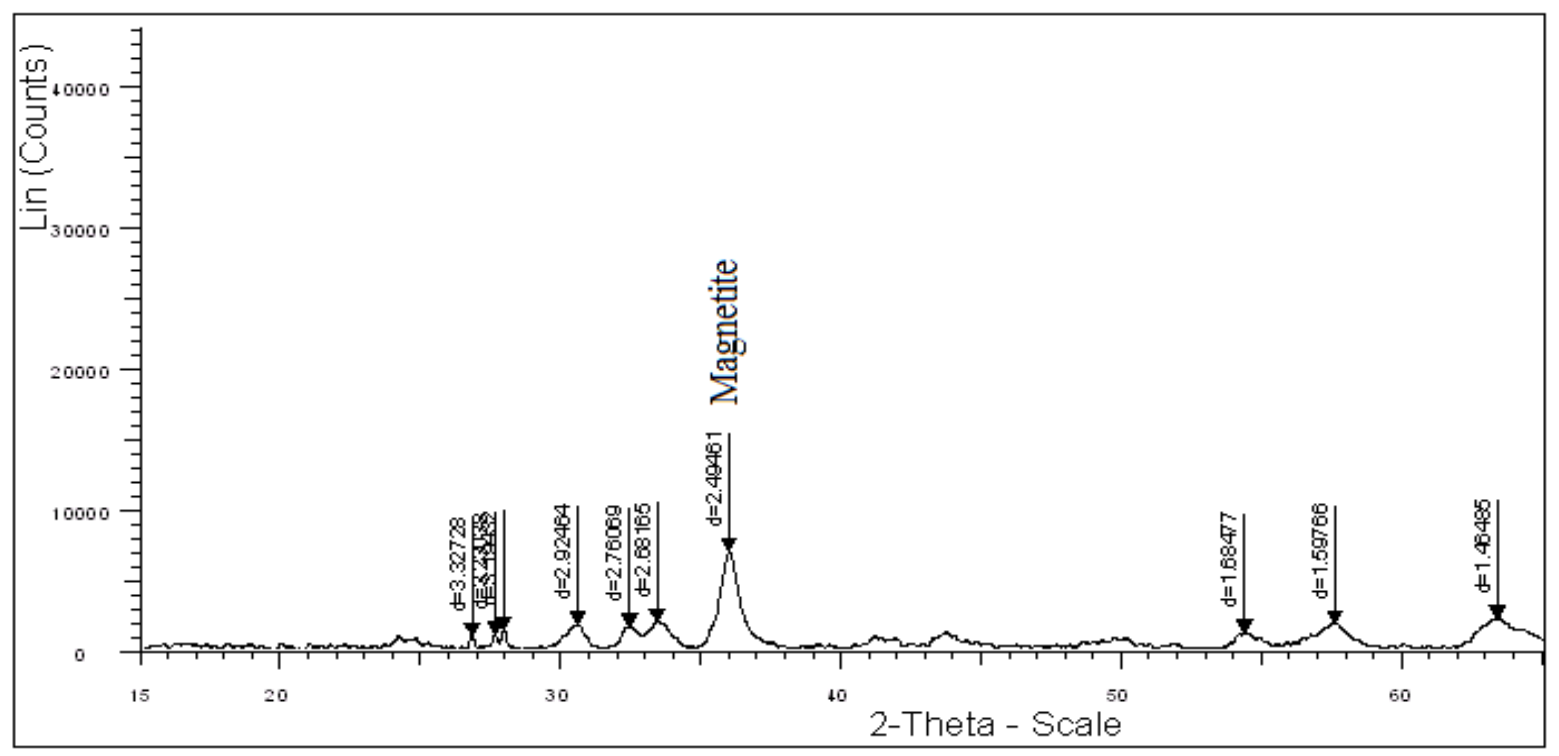

Figure 2(b) - XRD Spectra for reduced laterites from Ntendera region at level A with $65.32 \%$ iron 
X-ray diffraction spectra from both raw and heated laterite-charcoal mixture shows that goethite and hematite minerals were converted to magnetite. This is confirmed by the disappearing peaks from goethite ( $2 \Theta$ $\left.21.51^{\circ}\right)$ and hematite $\left(2 \Theta\right.$ of $\left.54.11^{\circ} \& 33.51^{\circ}\right)$ spectra of raw samples, and increasing intensity of the magnetite peaks $\left(2 \Theta\right.$ of $\left.36^{\circ}\right)$ in beneficiated samples. The common minerals found in the raw laterites are given in table 1 .

Table 1- Common minerals found in raw laterite from Tunyai Division

\begin{tabular}{|l|l|l|}
\hline Mineral name & $\mathbf{( 2 O )} \AA$ & Chemical formula \\
\hline Goethite & $\mathbf{2 1 . 5 1}^{\mathbf{0}}(\mathbf{4 . 1 3 \AA})$ & $\mathbf{F e O . O H}$ \\
\hline Brammallite & $62.49^{\circ}(1.485 \AA)$ & $\left(\mathrm{Na}, \mathrm{H}_{2} \mathrm{O}\right)(\mathrm{Al}, \mathrm{Mg}, \mathrm{Fe})_{2}(\mathrm{Si}, \mathrm{Al})_{4} \mathrm{O}_{10}\left[(\mathrm{OH})_{2},\left(\mathrm{H}_{2} \mathrm{O}\right)\right]$ \\
\hline Magnetite & $\mathbf{3 6}^{\mathbf{0}}(\mathbf{2 . 5 2 0 \AA})$ & $\mathbf{F e}_{3} \mathbf{O}_{4}$ \\
\hline Preiswerkite & $36.54^{\circ}(2.457 \AA)$ & $\mathrm{NaMg}_{2} \mathrm{Al}_{3} \mathrm{Si}_{2} \mathrm{O}_{5}(\mathrm{OH})_{4} \cdot n\left(\mathrm{H}_{2} \mathrm{O}\right)$ \\
\hline Siderite & $32.5^{\mathbf{0}}(2.762 \AA)$ & $\mathrm{FeCO}_{3}$ \\
\hline Hematite & $\begin{array}{l}\mathbf{5 4 . 1 1}^{\mathbf{0}}(\mathbf{1 . 6 9} \AA) \\
\mathbf{3 3 . 5 1}^{\mathbf{0}}(\mathbf{2 . 6 9} \AA)\end{array}$ & $\mathbf{F e}_{2} \mathbf{O}_{3}$ \\
\hline Shirokshinite, & $37^{\circ}(2.410 \AA)$ & $\mathrm{K}\left(\mathrm{NaMg}_{2}\right) \mathrm{Si}_{4} \mathrm{O}_{10} \mathrm{~F}_{2}$ \\
\hline Zincostaurolite & $37.60^{\circ}(2.390 \AA) \&$ & $4 \mathrm{Zn}_{4} \mathrm{Al}_{16}\left(\mathrm{Al}_{2}[]_{2} \mathrm{Si}_{8} \mathrm{O}_{40}\left[\mathrm{O}_{6},(\mathrm{OH})_{2}\right]\right.$ \\
& $33.43^{\circ}(2.678 \AA)$ & \\
\hline
\end{tabular}

After beneficiation, some of the common minerals obtained in the concentrates from the ten sampled regions are given in table 2 .

Table 2- Common minerals found in beneficiated laterites after magnetic separation

\begin{tabular}{|l|l|l|}
\hline Mineral name & $\mathbf{( 2 \Theta )} \AA$ & Chemical formula \\
\hline Magnetite & $\mathbf{3 6}^{\mathbf{0}}(\mathbf{2 . 5 2 0} \AA)$ & $\mathbf{F e}_{3} \mathbf{O}_{4}$ \\
\hline Manganoneptunite & $63.5^{\circ}(1.483 \AA)$ & $\mathrm{KNa}_{2} \mathrm{Li}_{(}\left(\mathrm{MnFe}^{2+}\right)_{2} \mathrm{Ti}_{2} \mathrm{Si}_{8} \mathrm{O}_{24}$ \\
\hline Biotite & $25.41^{\circ}(3.53 \AA)$, & $\mathrm{Ba}_{4}(\mathrm{Ti}, \mathrm{Nb})_{8} \mathrm{Si}_{4} \mathrm{O}_{28} \mathrm{Cl}$ \\
\hline Olkhonskite & $32.5^{\circ}(2.762 \AA)$, & $\left(\mathrm{Cr}^{3+}, \mathrm{V}^{3+}\right)_{2} \mathrm{Ti}_{3} \mathrm{O}_{9}$ \\
\hline Lindsleyite & $58^{\circ}(1.599 \AA)$. & $(\mathrm{Ba}, \mathrm{Sr})(\mathrm{Ti}, \mathrm{Cr}, \mathrm{Fe}, \mathrm{Mg})_{21} \mathrm{O}_{38}$ \\
\hline Lewisite & $30.38^{\circ}(2.940 \AA)$ & $(\mathrm{Ca}, \mathrm{Fe}++, \mathrm{Na})_{2}\left(\mathrm{Sb}, \mathrm{Ti}_{2}\right)_{2} \mathrm{O}_{7}$ \\
\hline
\end{tabular}

Charcoal in the mixture was heated in a limited current of air at a temperature range of $500-700{ }^{\circ} \mathrm{C}$ to produce $\mathrm{CO}$ gas in situ, which reduced hematite and goethite to magnetite. The reactions involved are given by equations 3 and 4 .

$2 \mathrm{C}(\mathrm{s})+\mathrm{O}_{2}(\mathrm{~g}) \longrightarrow 2 \mathrm{CO}(\mathrm{g})$

$3 \mathrm{Fe}_{2} \mathrm{O}_{3} \cdot \mathrm{H}_{2} \mathrm{O}(\mathrm{s})+\mathrm{CO}(\mathrm{g}) \longrightarrow 2 \mathrm{Fe}_{3} \mathrm{O}_{4}(\mathrm{~s})+\mathrm{CO}_{2}(\mathrm{~g})+3 \mathrm{H}_{2} \mathrm{O}(\mathrm{g})$

Since magnetite is more attracted to the magnet than goethite and hematite, magnetite was able to be separated using a strong magnet. This new technique of beneficiation provides a convenient method which when used, may help to exploit iron from laterite/murrams materials than relying on the few iron ore deposit available in the country. Elemental composition of raw, concentrate and tailing was analyzed using AAS and given in figure 3. 


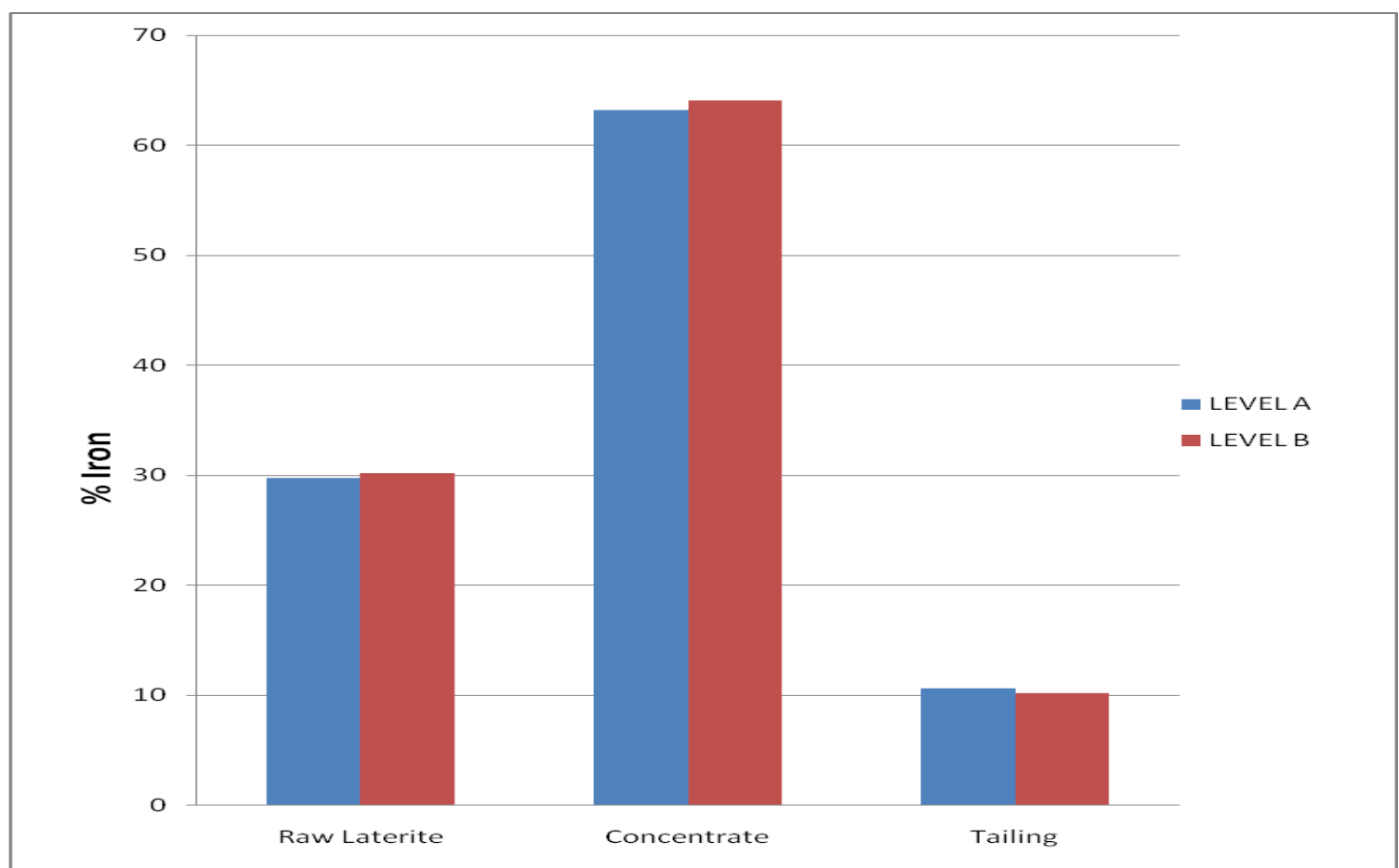

Figure 3- Percentage Iron in Raw, Concentrate and in the Tailing for Both Level A \& B

From the analysis, percentage iron in raw laterites ranged between 28 percent and 31 percent. The results show that iron is uniformly distributed in all the ten sampled regions, with a composition which is convenient for extraction. These values are greater than the values of other laterites in different parts of the country. For instance, laterites in Ruiru contains 15 to 28 percent iron ${ }^{13}$, Ruguru location in Nyeri District contains 18 percent Fe, Kiganjo in Nyeri District 17 percent Fe, Kiria-ini in Murang'a District contains 24 percent Fe, Tala in Machakos District contains 25 percent Fe, and Kairo in Murang'a District contains 10 percent $\mathrm{Fe}^{14}$. The iron levels in Tunyai laterites also compares favorably with iron ores in other countries. In Itakpe region in Nigeria, some iron ores used contains 25 to 30 percent iron ${ }^{10}$. In Sancy District (France), iron is mined from calcareous ore with 32 percent iron. In U.S. in the Mesebi Range, iron ores contains 34 percent iron while in Frodigham District (U.K), Brown ore contains 18 to 24 percent iron ${ }^{9}$. The values obtained in Tunyai Division are better than those of some iron ores in some countries.

This technique of enriching iron in the heated laterite mix with charcoal was able to increase the percentage of iron in laterites from about 30 to 64 percent, which represents 35 percent increase. This percentage increase matched with that of the available iron ores in other countries. In Kenya, iron ores in Marimante in Meru contains 46 percent iron and Macalder in South Nyanza contains 45.25 percent iron ${ }^{4}$. In Krivoi-Rog District in Russia, hematite ore contains 61.0 percent iron, magnetite ore at Kiruna in Sweden contains 65-68 percent and limonite ore at Mesabi District in U.S. contains 59.37 percent iron. Brazilian Itabirite found at the Ponto Verde iron ore contains 44.5 percent $\mathrm{Fe}^{9,15,16}$. From this study, the newly developed technique is economical compared to the convectional known methods of direct and indirect froth flotation, which requires use of chemicals like frothing agent, collectors, activators and depressants.

\section{CONCLUSIONS}

The study shows that iron in laterite can be concentrated using magnetic separation after heating a mixture of laterite with charcoal in a limited current of air. This occurs because goethite and hematite minerals in laterite are converted to magnetite with a percentage increase from about 30 to 64 percent iron. The beneficiated laterite can therefore be fed in the blast furnace.

\section{$\mathrm{V}$ ACKNOWLEDGEMENTS}

The researchers acknowledge Kenyatta University, Department of Geology and Mines, Ministry of Environment and Natural Resources and Embu University College (A Constituent College of the University of Nairobi) for their substantial help in the course of the ongoing research.

REFERENCES

[1] Cotton et al., (2004). Advanced Inorganic Chemistry. Wiley-India, $6^{\text {th }}$ edition, pp. 775-777. 
[2] Preston, C. (2008). Paleoecological Significance of the Banded Iron-Formation: American Geological Institute.Economic Geology. 68 (7): 1135-1143.

[3] Kiruna Iron Ore Mine Sweden, (2010).Mining-technology.com. http://www.miningtechnology.com/projects/kirunaRetrieved 2010-08-29.

[4] Du Bois, C.G.B., Walsh, J. (1970). Minerals of Kenya. Geological survey of Kenya, Bulletin No.11 pp. 34-36.

[5] China Mining Association (2011). Posted in http://www.chinamining./news/20110532/1306112936d45 671. html. Accessed on 25/12/2012.

[6] Hill et al., (2000). Geochemical evolution of a palaeolaterite: "The Interbasaltic formation, Northern Ireland" Chemical Geology, 166, 65.

[7] Adeyemi, G. O. and Wahab, A. K. (2008). Variability in the geotechnical properties of alateritic soil from south western Nigeria: Bulletin of Engineering and the environment, 67(4),579-584.

[8] Carter, et al., (2007). "Beneficiation". Ceramic materials: science and engineering. Berlin: Springer. P.347.

[9] Boltz, C. L. (1970). "Iron and Steel" in Materials and Technology, Vol III.METALS AND ORES. t.j.w. Van Thoor,, General Editor. Chapter 3. Longman and J.H. De Bussy.

[10] Umunakwe, P. U.(1985). "Developing a new mine- The Itakpe case". Proc. Annual Conf. of Nigeria Mining and Geosciences Society, Jos, Nigeria.

[11] Sharma, D. P. (2004). Iron ore and its beneficiation. Indian Science Abstracts, 40, 465-468.

[12] Purwanto et al.,(2003). Recovery of magnetite from leached laterite residue by magnetic separation. Iron and Steel Institute of Japan International, 14:1919-1926.

[13] Keru, G. K., (2011). Concentration of iron in murrams (laterite) from Ruiru area, Thika District, Kenya to asses economic viability. Kenyatta University, pp. 50-66.

[14] Muriithi, N.T. (1985). Iron Content of Samples of Black Marrums and Red Ochre from different parts of Kenya. Kenya Journal of Science and Technology. 6 :103-108.

[15] Iwasaki, I. (1983). Iron Ore Flotation, Theory and Practice. Mining Engineering, SME, pp. 622-631.

[16] Iwasaki, I. and Numela, W. (1986). Iron ore flotation. in: somasundaran, p., ed., Advances in Mineral Processing. Littleton, Colorado, SME, Chapter 18. pp. 308-342. 